\title{
Influencing Factors of the International Payment Service Quality at Joint Stock Commercial Bank for Investment and Development of Vietnam
}

\author{
Thi-Thu TRAN ${ }^{1}$, Thi Quynh-Anh NGO², Thi Ngoc-Anh CUNG ${ }^{3}$, Thi-Giang NGUYEN ${ }^{4}$, \\ Dang-Duong VU ${ }^{5}$, Phi-Hung NGUYEN ${ }^{6}$, Jung-Fa TSAI ${ }^{7}$
}

Received: July 18, 2020 Revised: August 23, 2020 Accepted: September 03, 2020

\begin{abstract}
International payment is an essential part of the economy, which is beneficial to both commercial banks and trading enterprises. Moreover, service quality, which has been a key point of discussion for decades, relates to customer satisfaction. This study aims to investigate the factors influencing international payment service quality at the Join Stock Commercial Bank for Investment and Development of Vietnam (BIDV) from 2015 through 2019. This research deploys both quantitative and qualitative methods to discuss the effects of these components. Statistical data was examined through different tests, including reliability analysis, correlation, and regression analysis by SPSS 16.0. The authors obtain and analyze 157 valid responses from customer surveys, then by applying an integration SERVPERF and PSQM model, identify five main components: Reliability, Tangibles, Assurance, Convenience, and Responsiveness, which explain how the customer perceives the service quality of international payment activities at BIDV. The results show that these five factors have a positive relationship with service quality, in which, Reliability has the most significant impacts on service quality level. Besides, the findings not only contribute to the literature but also give some practical implications for BIDV to improve its international payment service quality and help them to obtain customer satisfaction in the fast-changing environment.
\end{abstract}

Keywords: Service Quality, International Payment, BIDV, SERVPERF, SERVQUAL

JEL Classification Code: G21, G23, G32, H21

\section{Introduction}

${ }^{1}$ First Author, Faculty of Business, FPT University, Hanoi, Vietnam. Email: tranthithu998@gmail.com

${ }^{2}$ Faculty of Business, FPT University, Hanoi, Vietnam.

Email: quynhanh03071998@gmail.com

${ }^{3}$ Faculty of Business, FPT University, Hanoi, Vietnam.

Email: cunganhngoc84@gmail.com

${ }^{4}$ Faculty of Business, FPT University, Hanoi, Vietnam.

Email: giangnths140548@fpt.edu.vn

${ }^{5}$ Faculty of Business, FPT University, Hanoi, Vietnam.

Email: duongvdhs130259@fpt.edu.vn

${ }^{6}$ Corresponding Author. PhD Researcher, Faculty of Business, FPT

University, Hanoi, Vietnam [Postal Address: Hoa Lac High-Tech

Park, Km 29, Thang Long Boulevard, Hanoi, 100000, Vietnam]

Email: hungnp30@fe.edu.vn

${ }^{7}$ Department of Business Management, National Taipei University of Technology, Taipei, Taiwan. Email: jftsai@ntut.edu.tw

(c) Copyright: The Author(s)

This is an Open Access article distributed under the terms of the Creative Commons Attribution Non-Commercial License (https://creativecommons.org/licenses/by-nc/4.0/) which permits unrestricted non-commercial use, distribution, and reproduction in any medium, provided the original work is properly cited.
After becoming an official member of the WTO World Trade Organization in 2007, Vietnam's economy has progressively integrated into the world economy. The opening economy leads to a higher demand for trading transactions related to the international payment field. Moreover, there are more private joint-stock banks, foreign banks, and financial companies providing international payment services, in order to foster the rapid growth of both domestic and international trades. Customers are seen as banks' survival and growth. Therefore, the provision of high-quality services increases the rate of customer retention, attracts new customers through word-of-mouth communication, increases productivity, expands the market share, reduces staff turnover and operating costs, and improves employee morale, financial performance, and profitability (Hinson et al., 2006). Based on these facts, it is essential to find out the main factors that impact on the quality of international payment activities, for further development and enhancement.

This research investigates international payment service quality at BIDV, BIDV is the longest established 
financial institution in Vietnam. This bank is listed in the Top 2000 world's largest companies; Top 400 world's largest banks. In terms of international payment, BIDV has provided different types of services relating different methods such as remittance, collections, documentary credit. using an integrating model based on the SERVPERF and PSQM techniques to evaluate BIDV's international payment service quality. The study employs a qualitative method to analyze the secondary data and quantitative methods to examine primary data from the survey (online $\&$ offline). The survey was conducted through mail and at the counters in some big cities of Vietnam. Data collected from the survey was analyzed by SPSS 16.0 to determine the factors affecting the quality of international payment at BIDV.

This paper contains seven main parts. Along with the introduction, a literature review is presented in Section 2. Section 3 provides the research methodology applied. Section 4 shows the data analysis and the findings from the results. From that, the recommendations to improve BIDV international payment service quality are given in Section 5. The last two parts will present limitations and suggestions for further research as well as the conclusion of the research.

\section{Literature Review}

\subsection{General Theories of International Payment}

International payment is not only a profitable activity of commercial banks but also one of the center activity of other trade activities at the bank. Thereby, export-import finance, international credit and capital mobilization activities at commercial banks are promoted based on the participating in international payment service of clients at banks. As a result, the improvement of this activity will help commercial banks have more opportunities in increasing their benefits from other services, such as foreign currency trading, mobilizing capital, especially foreign currency capital. There are four main popular international payment methods: cash in advance, open account, collection of payment, and documentary credit.

Firstly, cash in advance is a payment method, which requires the buyer pays the seller prior the shipment of the goods (Edward, 2002). The cash payment is received before, and independently of, the shipment of goods. This method of payment is made either by bank draft or check or through a wire payment to the bank account specified by the seller/ exporter.

Secondly, open account is a payment method, in which the goods are shipped and delivered before payment is due, typically 30,60, 90 days in international sales. The seller ships the goods and sends invoice together with the other documents to the buyer, who is invited to pay the agreed amount on the appointed date into the account indicated by the exporter (Jan, 2004).

Thirdly, collection, according to The Uniform Rules for Collections, 1995 Revision, ICC Publication No. 522 - URC 522 (Commerce, 1995), means the handling by banks of documents in accordance with instructions received, in order to obtain payment and/or acceptance; or deliver documents against payment and/or against acceptance; or deliver documents on other terms and conditions. In fact, there are two types of collection: clean collection and documentary collection.

Finally, regarding to documentary credit, The Uniform Custom and Practice for Documentary Credits, ICC Publication No. 600 - UCP 600 (ICC, 2006), credit means any arrangement, however named or described, that is irrevocable and thereby constitutes a definite undertaking of the issuing bank to honor a complying presentation.

Payment methods, which are the ways the buyer makes payment to the seller, play an essential role in trade contracts for not only international trade but also in domestic trade. There are four main popular international payment methods: cash in advance, open account, collection of payment, and documentary credit. In the context of increasingly integrated world economy, international payment is seen as a bridge connecting domestic economy with international economy. It plays such a significantly vital role in a large number of economic activities, such as: export-import goods and services, foreign investment, foreign exchange and international finance. Without international payment services, the foreign economic activities have considerable difficulty in existing and developing. In contrast, if this services are conducted in quick, safe and accurate way, it will help the circulation of goods - money between buyers and sellers process more smoothly and efficiently.

Phan et al. (2019) identified potential factors affecting international bank card users. They concentrated on increasing the usefulness and reducing potential disadvantages of international bank cards. Nguyen (2020) applied multivariate data analysis techniques to evaluate the factors affecting the intention to use digital banking in Vietnam. Their results presented the necessity of digital transformation of traditional banking activities today, and banks need to build information security layers to insure customers, but at the same time, the services need ease of use to avoid annoying customers.

\subsection{Service Quality}

Services are known as the critical components of economics, and are mostly intangible and not stored. They are consumed at the point of sale (Kotler et al., 2014). According to the American Society for Quality, quality is defined as the collectivity of characteristics and features 
of products or services that underpin its capacity to meet implied or stated needs (Jay \& Barry, 2009; Le, 2020; Lee, 2017). Tabash (2019) and Baber (2019) measured the consumers' perspective using E-SERVQUAL to explore critical factors of service quality of Islamic banks in the Kingdom of Saudi Arabia and Malaysia. ISO 8002 defined service quality as an object's attributes, which make that object have the ability to satisfy stated or potential requirements. From that, the authors define international payment activities quality of commercial banks as the collection of attributes related to international payment activities at banks, making them have the ability to satisfy customers' requirements.

\subsection{Conceptual Framework}

It is evident that measuring quality in the service sector is harder than the manufacturing sector because quality evaluations are not only based on the outcome of service, but are also related to the service delivery process. There are previous studies that determined the criteria for evaluating service quality through the evaluation model. Parasuraman et al. (1985) and Zeithaml et al. (1988) are known as the first mover of service quality researching when providing Service quality model - SERVQUAL model in which service quality is assessed through the gap between "expectation" - $(\mathrm{E})$ and "perception" - (P).

However, Cronin and Taylor (1992) proposed a performance-based measure of service quality called the SERVPERF model, which controverted the SERVQUAL model and determined that service quality is a form of consumer attitude. In general, this scale was built based on the SERVQUAL model and had the same five primary factors in evaluating quality: Tangibles, Reliability, Assurance, Empathy, and Responsiveness. In detail, (1) Tangibles are factual information which is visible to the clients; (2) Responsiveness is the banking employees' willingness to provide services and help customers; (3) Reliability is the ability of a firm to perform the promised service dependably and accurately; (4) Assurance refers to "knowledge and courtesy of employees and their ability to convey trust and confidence; (5) Empathy concerns the individualized cares and attention that a firm provides to its customers.

The five factors are evaluated based on the perceptions or performance of service, and not based on the customer's "expectations." There are several advantages of using the SERVPERF scale instead of the SERVQUAL scale in evaluating service quality. First, SERVPERF model has been proved to be a superior measurement of service quality (Brown, Churchill Jr, \& Peter, 1993; Jain \& Gupta, 2004), especially the quality of banking services in developing countries like India (M Adil \& Ansari, 2012; Mohd Adil, 2012, 2013). Second, the questionnaire in the SERVPERF model (22 items) is half shorter than in SERVQUAL (44 items). Hartline and Ferrell (1996) and Babakus and Boller (1992) both stated that the SERVPERF model helps save time and is easier to understand for the respondents. Gronroos (2000) also applied the Perceived Service Quality Model (PSQM) technique to obtain three factors affecting service quality: technical quality, functional quality and corporate image. Their findings showed that technical service quality is the outcome generated by the service to the customers, functional service quality is the process of service delivery to the customer, and the image of the company refers to how customers perceive the company.

\subsection{Research Model and Hypothesis}

In the scope of this research, an integration SERVPERF and PSQM model is applied to evaluate international payment activities quality at BIDV; in which the four factors (Tangibles, Responsiveness, Reliability, Assurance) are chosen based on SERVPERF model and Convenience is chosen according to the functional aspect from PSQM model.

Tangibles: The physical facilities and equipment at transaction centers providing for the bank's customers, the appearance of bank employees.

Responsiveness: The bank staffs' willingness and readiness to provide services and help customers.

Reliability: The ability of the bank to perform services precisely and on time, right for the first time.

Assurance: The trust in the bank's services, employees' specialized skills, and serving attitude as well.

Convenience: How convenient the services are presented and provided in terms of extensive correspondent network, bank's transaction locations, and transaction procedure.

Thus five hypotheses are proposed as the following:

H1: Tangible components have a positive relationship on the service quality. That means, the higher/lower the tangible factor; the higher/lower the customer evaluates the service quality.

H2: Reliability component has a positive relationship with the service quality. That means, the higher/lower the reliability factor; the higher/lower the customer evaluates the service quality.

H3: Responsiveness component has a positive relationship with the service quality. That means, the higher/ lower the responsiveness factor; the higher/lower the customer evaluates the service quality.

H4: Assurance component has a positive relationship with the service quality. That means, the higher/lower the assurance factor; the higher/lower the customer evaluates the service quality. 


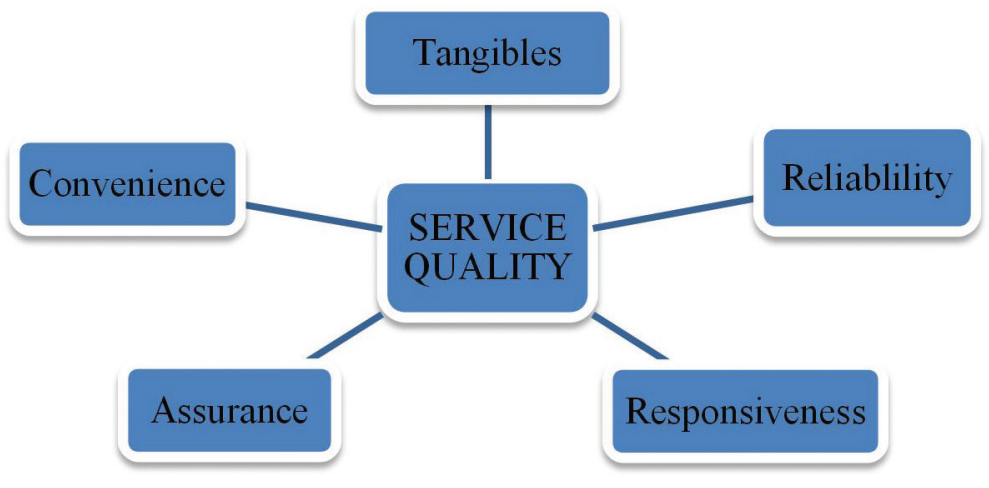

Figure 1: Proposed model

H5: Convenience component has a positive relationship with the service quality. That means, the higher/lower the empathy factor; the higher/lower the customer evaluates the service quality.

Currently, there are many research articles about the service quality in general and the bank service quality in specific. However, the quality in a specific activity of a commercial bank has not been studied much. To specify, in some Vietnamese research, almost all studies are about the service quality of trade finance activities, applying for only two payment methods: documentary credit and collection of payment at commercial banks. Meanwhile, international payment (which also contains open account and cash in advance method) has not concentrated on the specific bank as BIDV yet. Besides, all the research articles about trade finance at BIDV used data before 2015, which is not updated with continuous changes. Regarding to research method, almost all previous studies about the international payment service quality showed analysis based on a qualitative method; however, it was not based on a quantitative method to confirm the rationality of the applied models and how the components impact on the international payment service quality. Therefore, this study will determine and analyze the influencing factors of international payment service quality at BIDV through both qualitative and quantitative methods, with a more updated data to provide a better picture of the bank's operations in the overall development of the Vietnam foreign trade economy.

\section{Methodology}

\subsection{Designing Questionnaire}

In the scope of this research, the questionnaire was designed in Vietnamese, and divided into three main parts (shown in Appendix):

Part I includes questions related to vital information of customers to classify participants as well as asks about which international payment services they have used in BIDV.
Part II contains questions for collecting customers' assessments about the perceived service (international payment service) quality of BIDV, following five independent factors, and one dependent factor in the research model.

Part III are open questions that require customers to provide personal recommendations to improve the international payment service quality at BIDV.

In this questionnaire, Part II consists of 21 variables in total. Assessing the perceived service quality under the proposed research model comprises 18 variables to measure five service quality components: Tangibles, Responsiveness, Reliability, Assurance, and Convenience; the three remaining variables are used to measure the service quality. This measurement is based on a 5-point rating scale which corresponds to $1=$ very disagree, $2=$ somewhat disagree, $3=$ normal (neither agree nor disagree), $4=$ somewhat agree, $5=$ strongly agree.

\subsection{Sampling and Collecting Data}

This study has 21 variables in total. According to Hair et al. (2010), the sample size should be at least five responses per 1 observed variable. In order to collect at least five responses per 1 observed variable, the study needs to collect at the minimum, a sample size of 105 responses. 565 questionnaires were given to customers to obtain this sample size.

Data for the study were collected utilizing mail surveys with import-export companies in Vietnam, direct surveys at counters, and personal interviews. For direct surveys and personal interviews, data collection was carried out at counters in some big cities of Vietnam. Questionnaires were provided to customers having free time and ready to answer questions. The survey process took place from January 2020 to the end of March 2020. For the mail survey, exportimport enterprises' information was sought on trangvang. com and some groups for the export-import job on social media networks, and then these businesses were sent surveys through email. Questionnaires were mailed in two batches 
- one in January 2020 and one in February 2020. In the beginning, data will be input and screened to find out missing samples. After removing all invalid samples, the authors encode and analyze data in SPSS 16.0 as the following:

\subsection{Descriptive Analysis}

Descriptive analysis is the analysis of data collection between valid or non-valid answers through the mean, percentage, mode, and Variance of variables. After analyzing these data, the results can be used to describe the data obtained.

\subsection{Reliability Analysis}

According to Tavakol and Dennick (2011), Cronbach's alpha is a popular measure of a scale's internal consistency describing the extent to which all the items in a test measure the same concept or construct, and hence it is connected to the inner-relatedness of the items within the test.

The alpha's $(\alpha)$ value may be from negative infinity to 1 , but only positive values have meaning. Generally, the alpha coefficient ranges between 0 and 1 , and the more this value increases, the higher degree of correlations between items increases. In this study, the scales having an alpha coefficient equal to or greater than 0.7 are accepted.

Besides evaluating the scales' Reliability, Cronbach's alpha analysis supports checking if any item is not consistent with the rest of the scale through item-total correlations. Variables having greater than 0.3 item-total correlation will be accepted; in contrast, the others having smaller than 0.3 item-total correlations will be removed from the analysis data.

\subsection{Exploratory Factor Analysis}

Descriptive factor analysis is one useful technique for data reduction and summarization. The sampling adequacy for each variable in the model is measured by Kaiser-MeyerOlkin (KMO). There are two cases: if KMO's value is between 0.5 and 1.0 and Sig. is smaller than 0.5 , it indicates that the factor analysis is apt; on the contrary, if KMO has a value smaller than 0.5 or Sig. is more significant than 0.5 , it indicates that the factor analysis is inappropriate.

\subsection{Correlation Analysis}

The Pearson correlation coefficient ( $\mathrm{r}$ ), which is given from +1 to -1 , measures the degree of correlation between the two variables. In the case of $r<0$, it indicates a negative correlation between the two variables. In the case of $r=0$, it shows no correlation. In the case of $r>0$, it demonstrates a positive correlation between the two variables.

\subsection{Regression Analysis}

Regression analysis is used as a technique for analyzing the relationship between the dependent variable (service quality) and independent variables (tangibles, Responsiveness, Reliability, Assurance, and Convenience) to measure the influence of each independent variable on the dependent variable and achieving the prediction about the change in the dependent variable if there is any change in independent variables.

\section{Research Analysis and Results}

\subsection{Respondent Profile}

The survey was collected in three months from January to March 2020. The total of the collected sample is 189 , which includes 75 online survey samples and 114 offline survey samples. After rejecting the invalid samples from both online and offline research, 157 samples were accepted for analysis. In which, 34 samples were statedowned enterprise, 92 samples were private enterprise, and 31 samples were foreign-invested enterprise (accounted $21.7 \%, 58.6 \%$, and $19.7 \%$ respectively) as shown in Fig 2 . The size of the business was divided into two groups of large corporate and SME (small and medium enterprise). The total numbers of those businesses account for $26 \%$ and $74 \%$ respectively. Nearly $73 \%$ of the respondents use more than one bank; $27 \%$ of the respondents only use BIDV for their international payment. The average frequency of using IP activities at BIDV is about 10-20 times per month.

\subsection{Reliability Analysis}

Table 1 illustrates that the six scales are reliable, with Cronbach's Alpha value greater than 0.7. Otherwise, all 21 observed variables have corrected item-total correlation more than 0.3 ; hence, they are accepted and will be analyzed in the next step.

\subsection{Exploratory Factor Analysis}

\section{a, Exploratory factor analysis for factor affecting} service quality (independent factors)

The exploratory factor analysis for independent factor analysis is adequate, with a KMO value of 0.881 , more significant than 0.5 and Sig. Value of .000, smaller than 0.05 (as shown in Table 2 and 3). The Cumulative \% of Variance explained for factors is $69.792 \%$ (greater than $50 \%$ ), so the model is suitable for research. The five components can explain $69.792 \%$ of service quality variance. In conclusion, all variables are included in the research model in the next analyzing test. 

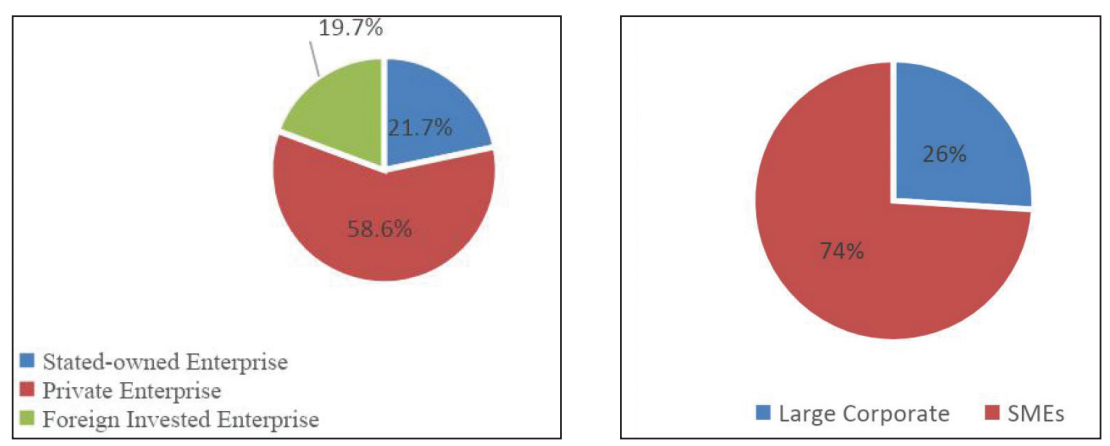

Figure 2: Types of Business and Size of Business

Table 1: Reliability Analysis Result

\begin{tabular}{|c|c|c|c|}
\hline Factors & Measures & $\begin{array}{l}\text { Corrected } \\
\text { Item-Total } \\
\text { Correlation }\end{array}$ & $\begin{array}{l}\text { Cronbach's } \\
\text { Alpha if Item } \\
\text { Deleted }\end{array}$ \\
\hline \multicolumn{4}{|c|}{ TANGIBLES scale: Cronbach's Alpha $=.785$} \\
\hline TA1 & Adequate and visually appealing physical facilities & .557 & .749 \\
\hline TA2 & Up-to-date equipment. & .561 & .746 \\
\hline TA3 & Well-dressed and professional employees & .639 & .709 \\
\hline TA4 & Suitable supporting facilities & .619 & .717 \\
\hline \multicolumn{4}{|c|}{ RELIABILITY scale: Cronbach's Alpha $=.821$} \\
\hline RE1 & Providing services as their commitment and advertisement & .742 & .741 \\
\hline RE2 & Handling transaction accurately, without unexpected errors & .697 & .753 \\
\hline RE3 & Secured information of customers and their transactions & .597 & .803 \\
\hline RE4 & Supporting special and complex transactions & .610 & .791 \\
\hline \multicolumn{4}{|c|}{ RESPONSIVENESS scale: Cronbach's Alpha $=.823$} \\
\hline RS1 & Providing various types of products and services & .648 & .780 \\
\hline RS2 & Giving reasonable, flexible and competitive service fees & .669 & .766 \\
\hline RS3 & Processing transactions quickly & .652 & .777 \\
\hline RS4 & Well handling customers' feedbacks and complaints & .629 & .785 \\
\hline \multicolumn{4}{|c|}{ ASSUARANCE scale: Cronbach's Alpha $=.864$} \\
\hline AS1 & $\begin{array}{l}\text { High professional knowledge of banking staff in procedures, regulations and } \\
\text { international customs }\end{array}$ & .735 & .814 \\
\hline AS2 & Staffs' good serving attitude and willingness to support customers and have & .864 & .785 \\
\hline AS3 & Being highly credible and on the top choice for international payment service. & .724 & .823 \\
\hline \multicolumn{4}{|c|}{ CONVENIENCE scale: Cronbach's Alpha $=.803$} \\
\hline $\mathrm{CO} 1$ & Having wide network of correspondent banks network & .666 & .714 \\
\hline $\mathrm{CO} 2$ & Having many transaction locations which is convenient for customers & .712 & .683 \\
\hline $\mathrm{CO} 3$ & Easy, simple and proper transaction procedures & .601 & .807 \\
\hline \multicolumn{4}{|c|}{ SERVICE QUALITY scale: Cronbach's Alpha $=.858$} \\
\hline SERV1 & Generally meeting customer's needs & .681 & .848 \\
\hline SERV2 & Being satisfied with this service quality at the bank & .780 & .755 \\
\hline SERV3 & Being willing to introduce this service at the bank to others & .740 & .794 \\
\hline
\end{tabular}


Table 2: Results of Exploratory Factors Analysis for Independent Factors

\begin{tabular}{|c|c|c|c|c|c|}
\hline & & & ompone & & \\
\hline & 1 & 2 & 3 & 4 & 5 \\
\hline RE2 & .842 & & & & \\
\hline RE1 & .788 & & & & \\
\hline RE3 & .692 & & & & \\
\hline RE4 & .634 & & & & \\
\hline RS2 & & .824 & & & \\
\hline RS3 & & .775 & & & \\
\hline RS4 & & .717 & & & \\
\hline RS1 & & .653 & & & \\
\hline AS1 & & & .839 & & \\
\hline AS2 & & & .827 & & \\
\hline AS3 & & & .799 & & \\
\hline TA3 & & & & .793 & \\
\hline TA4 & & & & .739 & \\
\hline TA1 & & & & 640 & \\
\hline TA2 & & & & .624 & \\
\hline $\mathrm{CO} 2$ & & & & & .839 \\
\hline $\mathrm{CO} 1$ & & & & & .771 \\
\hline $\mathrm{CO} 3$ & & & & & .766 \\
\hline Initial Eigenvalues & 6.957 & 1.657 & 1.542 & 1.353 & 1.053 \\
\hline$\%$ of Variance & 38.652 & 9.207 & 8.569 & 7.517 & 5.847 \\
\hline Cumulative Variance & 38.652 & 47.860 & 56.428 & 63.945 & 69.792 \\
\hline
\end{tabular}

Table 3: Results of Exploratory Factors Analysis for Independent Factors

\begin{tabular}{|l|c|}
\hline Component Matrix $^{\mathbf{a}}$ & Component \\
\cline { 2 - 2 } & 1 \\
\hline SERV2 & .909 \\
\hline SERV3 & .887 \\
\hline SERV1 & .852 \\
\hline Initial Eigenvalues & 2.337 \\
\hline Cumulative \% & 77.913 \\
\hline
\end{tabular}

b, Exploratory factor analysis for service quality scale (dependent factor)

The KMO value of analysis is 0.718 , more significant than 0.5 and Sig. Value is smaller than 0.05 , which illustrates the adequacy of data. The analysis extracts one component, which has eigenvalues of 2.337 (greater than 1). All three service quality items define this component with factor loadings of more than 0.5 . The cumulative Variance is $77.913 \%$, so this component explains $77.913 \%$ of service quality variance. In short, the service quality scale includes three observed variables, extracted to one component SERV.

\subsection{Regression Analysis}

First, the correlation between service quality and the five factors-Tangibles, Convenience, Assurance, Responsiveness, and Reliability is indicated by positive values of Pearson correlation. In which, Reliability (RE) has the strongest Correlation with Service quality (SERV) with $\mathrm{r}$ equals 0.698 , and Convenience (CO) shows the weakest relationship with Service quality (SERV) with $r$ equals 0.579 . Pearson correlation values between independent components are quite high (greater than 0.3 ), so multicollinearity may exist. However, the VIF values of these factors are small (lower than two, as shown in Table 4). Therefore, the multiple collinearities do not appear in this case, and the regression model will be indicated. In Table 4 model summary, the Adjusted R-square 
value is 0.713 (higher than 50\%), which indicates that $71.3 \%$ of the Variance in service quality can be explained by these predictors (TA, RE, RS, AS, CO). The Durbin-Watson statistic shows a value of 1.437 (which ranges from 1 to 2); that means there is no autocorrelation in the sample. Moreover, the Sig. of $F$ test is less than 0.05 . Therefore, the dependent factor can be explained by the variables of five independent factors. The linear regression equation of the proposed research model after the regression analysis with coefficients described in Table 4 is shown as follows:

$$
\begin{aligned}
\mathrm{SERV}= & 0.197 * \mathrm{TA}+0.337 * \mathrm{RE}+0.219 * \mathrm{RS}+0.207 * \mathrm{AS} \\
& +0.166^{*} \mathrm{CO}
\end{aligned}
$$

The positive coefficients illustrate that the service quality has a positive relationship with independent variables. As a result, all the proposed hypotheses are confirmed. Otherwise, following the standardized coefficients, Reliability has the most substantial influence on the service quality (with Beta $=0.337$ ). Other factors impact on service quality is in the following order: Responsiveness, Assurance, Tangibles, and Convenience (with Beta equals 0.219, 0.207, 0.197, 0.166, respectively).

\section{Findings and Discussions}

\subsection{Discussions}

From the results of the regression model, we can evaluate the impact level of 5 independent variables on customer satisfaction when using international payment services, including: Responsiveness, Assurance, Reliability, Tangibles, and Convenience. The five factors have a relatively equal impact level, however, the Reliability is the factor that has the most influence, followed by Responsiveness, Assurance, Tangibles, and Convenience.

\begin{tabular}{|c|c|c|c|c|c|c|c|c|}
\hline \multicolumn{9}{|c|}{ Coefficients $^{a}$} \\
\hline \multirow{2}{*}{\multicolumn{2}{|c|}{ Model }} & \multicolumn{2}{|c|}{$\begin{array}{l}\text { Unstandardized } \\
\text { Coefficients }\end{array}$} & \multirow{2}{*}{$\begin{array}{c}\begin{array}{c}\text { Standardized } \\
\text { Coefficients }\end{array} \\
\text { Beta }\end{array}$} & \multirow{2}{*}{$\mathbf{t}$} & \multirow{2}{*}{ Sig. } & \multicolumn{2}{|c|}{ Collinearity Statistics } \\
\hline & & B & Std. & & & & Tolerance & VIF \\
\hline \multirow[t]{6}{*}{1} & (Constant) & .157 & .179 & & .873 & & & \\
\hline & TA & .162 & .047 & .197 & 3.443 & & .563 & 1.778 \\
\hline & $\mathrm{RE}$ & .338 & .054 & .337 & 6.208 & & .622 & 1.608 \\
\hline & RS & .159 & .039 & .219 & 4.054 & & .631 & 1.586 \\
\hline & AS & .135 & .034 & .207 & 3.978 & & .678 & 1.476 \\
\hline & $\mathrm{CO}$ & .134 & .042 & .166 & 3.208 & & .688 & 1.453 \\
\hline \multicolumn{9}{|c|}{ a. Dependent Variable: SERV } \\
\hline \multicolumn{9}{|c|}{ Model Summary } \\
\hline \multicolumn{2}{|l|}{ Model } & \multicolumn{2}{|c|}{ R Square } & $\begin{array}{l}\text { Adjusted } \\
\text { R Square }\end{array}$ & \multicolumn{2}{|c|}{ Std. Error of the Estimate } & \multicolumn{2}{|c|}{ Durbin-Watson } \\
\hline 1 & $.850^{\mathrm{a}}$ & \multicolumn{2}{|c|}{.722} & .713 & \multicolumn{2}{|c|}{.37558} & \multicolumn{2}{|c|}{1.437} \\
\hline \multicolumn{9}{|c|}{ a. Predictors: (Constant), CO, RS, RE, AS, TA } \\
\hline \multicolumn{9}{|c|}{ b. Dependent Variable: SERV } \\
\hline \multicolumn{9}{|c|}{ ANOVA $^{a}$} \\
\hline \multicolumn{2}{|l|}{ Model } & \multicolumn{2}{|c|}{ Sum of Squares } & df & Mean Square & $\mathbf{F}$ & \multicolumn{2}{|c|}{ Sig. } \\
\hline \multirow[t]{3}{*}{1} & Regression & \multicolumn{2}{|c|}{55.454} & 5 & 11.091 & 78.622 & \multicolumn{2}{|c|}{$.000^{b}$} \\
\hline & Residual & \multicolumn{2}{|c|}{21.301} & 151 & .141 & & & \\
\hline & Total & & & 156 & & & & \\
\hline a. Depe & dent Variable & ERV & & & & & & \\
\hline b. Pred & tors: (Consta & $\mathrm{CO}, \mathrm{RS}$ & $\mathrm{AS}, \mathrm{TA}$ & & & & & \\
\hline
\end{tabular}

Table 4: Service Quality Coefficients and Model Summary ${ }^{\mathrm{b}}$ of ANOVA test 
This result in which Reliability has the most influence is completely consistent with the reality of international payment services of BIDV. In international payment transactions, the accuracy and safety factor is always highly focused because it directly affects the business activities of their customers. In fact, BIDV was received the award "The best local trade finance house 2012" from Euromoney magazine. Furthermore, according to BIDV Annual Report 2009, BIDV has also received other award from reputable banks in the world such as JP Morgan Chase, Bank of New York Mellon, Citibank, and Wells Fargo for Straight Through Processing (STP). These achievements have affirmed the prestige, position of BIDV as one of the leading prestigious commercial banks of Vietnam, which always provides the trade finance products and services to customers with good quality.

In addition, the Responsiveness factor shows that customers in international payment transactions appreciate the bank's ability in terms of processing time, and the diversity and flexibility in providing different types of products to match their needs. The next affecting factor in this case is Assurance. This component refers to the employees' ability to perform services for customers. Actually, in order to efficiently support and consult transactions, especially complicated ones, the banking staffs always have to improve their professional knowledge not only in this field, but other related ones as well such as insurance, customs, and international transportation, etc. Besides, Tangibles factor also affects the quality of this service. This shows that the modernity of facilities, programs and applications of the banks have important roles in helping customers easily handle their transactions with the bank. This issue has become more and more meaningful in international payment services, especially in the context of the 4th industrial revolution with strong enhancement in technology nowadays. Last but not least, Convenience factor also has influenced on the quality of the bank. It reflects the ability of the bank in strengthening relationship with different correspondent banks in the world, as well as expanding a network of branches and transaction offices nationwide to provide the most convenience to the customers.

\subsection{Recommendations}

To begin with, as the above results, Reliability has the most influence on the quality of this service. Therefore, enhancing the bank's reputation in providing safe and accurate transactions is very important. It requires the banks to maintain and improve a system of processes day by day, in which the transactions are supervised and controlled carefully. By these ways, the banks can limit different type of risks, from both customers' side and the banks themselves' operational activities. Furthermore, in order to provide the reliable services to import-export companies, other requirement such as compliance with legal regulations (for example, foreign exchange management regulations, antimoney laundering regulations, etc.) should be always paid attention to.

To improve Responsiveness, BIDV, in particular, and other commercial banks, in general, should improve product policies by researching and implementing international payment packages. This package will allow BIDV to provide more comprehensive products and services per one transaction, such as international payment service along with insurance service or credit service. BIDV can take its competitive advantage of owning an insurance brand BIC to provide a more competitive price for this product package. Furthermore, BIDV should provide more valueadded services to attract more potential customers, such as help customers purchase information to appraise their export/import partners or provide programs/apps to check the authenticity of export-import documents when needed.

Regarding to Assurance factor, with the rapid changing and development in both economy and society nowadays. This component refers to the employees' ability to perform services for customers. Thus, to improve this factor, the essential thing needed to do is to develop the staffs' competency. BIDV, hence, should undertake training about international payment activities (such as policies, procedures, systems) regularly or encourage banking staff (especially international payment employees) to take CDCS certificate or concern more about the recruitment requirements.

Last but not least, Tangibles and Convenience are also necessary to be developed. First, the bank should yearly renovate the branches' tangibles such as facilities and equipment, especially, the degraded ones. Additionally, the staff at the branches, from the security team to bank tellers, should be trained about good and professional manners toward customers quarterly. Moreover, the bank should optimize the transaction procedures by cutting down unnecessary procedures or applying new technology to reduce manual work to improve its Convenience. Moreover, the bank needs to continuously build relationships with correspondent banks to leverage the support from them for international payment service.

\subsection{Limitations}

One limitation of this study is that the survey was conducted in only several representative transaction offices of BIDV. The questionnaire answered by customers is mostly based on their assessment of the service quality of these transaction offices. The answers from survey, sometimes, may be conducted by the employee individually. Therefore, it may reflect the personal views of such employees only, not evidence the official opinion from such enterprises. 
Therefore, some analyses and conclusions in this study are subjective and can be improved. Another limitation is that the time to carry out a survey, collect survey data as well as analyze data was limited. So for further research, data can be collected and analyzed more broadly and thoroughly in a longer period with a larger sample. With these improvements, it is expected that further studies may have higher practical values with more objective analysis and conclusions.

\section{Conclusion}

This research examines BIDV's international payment activities to analyze the components of the quality of its services and give recommendations to improve it. The research utilized both quantitative and qualitative methods. Regarding the quantitative method, the theoretical model used is based on the SERVPERF and PSQM model with 18 observed items classified into 5 components of service quality (one of the components in the initial theoretical model (Empathy) is replaced by a new component of service quality (Convenience)). With 157 valid responses, data is used to make reliability analysis, exploratory factor analysis, and regression analysis, as shown in part 4 . The regression analysis indicates that service quality has a positive relationship with the independent variables. The positive service quality of BIDV will be driven by the positive ability in Tangibles, Reliability, Responsiveness, Assurance, and Convenience. In terms of qualitative method, the result of the survey shows that the bank gain's customers' trust and give high service quality because of the following: transactions are handled accurately without unexpected errors; equipment, as well as supporting facilities, is up-todate and; employees' manners and qualification are right; many transaction locations are convenient for customers.

However, there remain some limitations related to technology, transaction processing time, correspondent bank network, products, or fees, which are suggested to be improved with the above solutions. This result confirms the importance of the five above aspects in enhancing service quality. From that, BIDV managers' may consider the value of five above factors to service quality and set up suitable policies as well as effectively allocate resources. Finally, this study recommended several solutions to enhance the quality of IP activities at BIDV, which will help improve the values of serving enterprises in international trade.

\section{References}

Adil, M, \& Ansari, S. A. (2012). Service quality and customer loyalty at Indian rural banks: An empirical test of an integrative model. Proceedings of the National Conference on Contemporary Issues in Business, Management \& Finance, University of Kashmir, India.
Adil, M. (2012). Efficacy of SERVPERF in measuring perceived service quality at rural retail banks: Empirical evidences from India. International Journal of Business Insights \& Transformation, 6(1), 52-63.

Adil, M. (2013). Modelling effect of perceived service quality dimensions on customer satisfaction in Indian bank settings. International Journal of Services and Operations Management, 15(3), 358-373.

Babakus, E., \& Boller, G. W. (1992). An empirical assessment of the SERVQUAL scale. Journal of Business Research, 24(3), 253-268.

Baber, H. (2019). E-SERVQUAL and its impact on the performance of Islamic banks in Malaysia from the customer's perspective. Journal of Asian Finance, Economics and Business, 6(1), 169175. https://doi.org/10.13106/jafeb.2019.vol6.no1.169

Brown, T. J., Churchill Jr, G. A., \& Peter, J. P. (1993). Research note: Improving the measurement of service quality. Journal of Retailing, 69(1), 127-139.

Cronin Jr, J. J., \& Taylor, S. A. (1992). Measuring service quality: A reexamination and extension. Journal of Marketing, 56(3), $55-68$.

Gronroos, C. (2000). Service management and marketing: A customer relationship management approach. Hoboken, NJ: John Wiley \& Sons.

Hair, J. F., Celsi, M., Ortinau, D. J., \& Bush, R. P. (2010). Essentials of marketing research (Vol. 2). New York, NY: McGraw-Hill/ Irwin.

Hartline, M. D., \& Ferrell, O. C. (1996). The management of customer-contact service employees: An empirical investigation. Journal of Marketing, 60(4), 52-70.

Hinson, R., Mohammed, A., \& Mensah, R. (2006). Determinants of Ghanaian bank service quality in a universal banking dispensation. Banks \& Bank Systems, 1(1), 69-81.

Jain, S. K., \& Gupta, G. (2004). Measuring service quality: SERVQUAL vs. SERVPERF scales. Vikalpa, 29(2), 25-38.

Jay, H., \& Barry, R. (2009). Operation management flexible version ( $9^{\text {th }}$ ed.). Upper Saddle River, NJ: Prentice Hall.

Kotler, P., Armstrong, G., Harris, L. C., \& Piercy, N. (2014). Principles of marketing ( $4^{\text {th }}$ ed.). Upper Saddle River, NJ: Prentice Hall.

LE, T. T. D. (2020). Determinants of Retail Banking Efficiency: A case of Vietcombank branches in the Mekong-Delta region. Journal of Asian Finance, Economics and Business, 7(7), 439451. https://doi.org/10.13106/jafeb.2020.vol7.no7.439

Lee, J. W. (2017). Critical factors affecting consumer acceptance of online health communication: An application of service quality models. Journal of Asian Finance, Economics and Business, 4(3), 85-94. https://doi.org/10.13106/jafeb.2017.vol4.no3.85

Nguyen, O. T. (2020). Factors affecting the intention to use digital banking in Vietnam. Journal of Asian Finance, Economics and Business, 7(3), 303-310. https://doi.org/10.13106/jafeb.2020. vol7.no3.303 
Nguyen, T. (2010). International payment and trade finance. Hanoi, Vietnam: Statistics Publisher.

Parasuraman, A., Zeithaml, V. A., \& Berry, L. L. (1985). A conceptual model of service quality and its implications for future research. Journal of Marketing, 49(4), 41-50.

Phan, D. T. T., Nguyen, T. T. H., \& Bui, T. A. (2019). Going beyond border? Intention to use international bank cards in Vietnam. Journal of Asian Finance, Economics and Business, 6(3), 315-325. https://doi.org/10.13106/jafeb.2019.vol6.no3.315

Tabash, M. I., Albugami, M. A., Salim, M., \& Akhtar, A. (2019). Service quality dimensions of E-retailing of Islamic banks and its impact on customer satisfaction: An empirical investigation of Kingdom of Saudi Arabia. Journal of Asian Finance, Economics and Business, 6(3), 225-234. https://doi. org/10.13106/jafeb.2019.vol6.no3.225

Tavakol, M., \& Dennick, R. (2011). Making sense of Cronbach's alpha. International Journal of Medical Education, 2, 53-55.

Zeithaml, V. A., Berry, L. L., \& Parasuraman, A. (1988). SERVQUAL: a multiple-item scale for measuring consumer perceptions of service quality. Journal of Retailing, 64(1), 12-40. 


\section{Appendix}

Survey About the Factors Influence International Payment Activities at BIDV

\section{GENERAL INFORMATION}

Please tick V on your chosen option.

All personal information you provide is confidential and only used for research purposes.

1. What is your type and size of your business?

1.1. Type of business:

$€$ State- owned enterprise

$€$ Private Enterprise

$€$ Foreign Invested Enterprise

$€$ Others:

1.2. Size of business:

$€$ Small and Medium Enterprise

$€$ Large Corporate

2. How many banks have you made international payment transactions up to now?

$€$ Only 1 bank

$€ 2-3$ banks

$€ \quad 3-4$ banks

$€$ More than 5 banks

3. How many times have you used international payment services at BIDV?

$€$ Have not used

$€$ Under 1 year

$€ 1-3$ years

$€ \quad 3-5$ years

$€$ More than 5 years

4. How frequent (per month) do you use international payment services at BIDV?

$€$ Under 5 times

$€$ 5-10 times

$€ 10-20$ times

$€ 20-40$ times

$€$ More 40 times

5. Which products of international payment do you use at BIDV?

5.1. Field:

$€$ Export Payment

$€$ Import Payment

5.2. Used payment methods:

$€$ Letter of Credit

$€$ Collection

$€$ International Remittance

$€$ Others:

\section{ASSESSMENT QUESTION}

(For those who have used international payment service at BIDV)

\section{Evaluation of service quality - Part I}

For each question below, your level of approval for BIDV's international payment activities is calculated by increasing the scale from 1 to 5 :

1- Very bad

2- Bad

3- Normal

4- Good

5- Very good 
$(*)$ : Required questions

\begin{tabular}{|c|c|c|c|c|c|c|c|}
\hline \multirow[t]{2}{*}{ No. } & \multirow[t]{2}{*}{ Encode } & \multirow[t]{2}{*}{ Description } & \multicolumn{5}{|c|}{ Degree } \\
\hline & & & 1 & 2 & 3 & 4 & 5 \\
\hline \multicolumn{8}{|c|}{ Tangibles* } \\
\hline 1 & TA1 & 1. Physical facilities are adequate and visually appealing. & $\square$ & $\square$ & $\square$ & $\square$ & $\square$ \\
\hline 2 & TA2 & 2. Up-to-date equipment. & $\square$ & $\square$ & $\square$ & $\square$ & $\square$ \\
\hline 3 & TA3 & 3. Employees are well-dressed and look professional & $\square$ & $\square$ & $\square$ & $\square$ & $\square$ \\
\hline 4 & TA4 & $\begin{array}{l}\text { 4. The supporting facilities are various and consistent with the type } \\
\text { of service industry (leaflets, website interface...). }\end{array}$ & $\square$ & $\square$ & $\square$ & $\square$ & $\square$ \\
\hline \multicolumn{8}{|c|}{ Reliability* } \\
\hline 5 & RE1 & $\begin{array}{l}\text { 1. The bank provides their services as their commitment and } \\
\text { advertisement. }\end{array}$ & $\square$ & $\square$ & $\square$ & $\square$ & $\square$ \\
\hline 6 & RE2 & $\begin{array}{l}\text { 2. The bank conduct accurate transaction without any unexpected } \\
\text { errors. }\end{array}$ & $\square$ & $\square$ & $\square$ & $\square$ & $\square$ \\
\hline 7 & RE3 & 3. Customers' and transactions' information is totally secured. & $\square$ & $\square$ & $\square$ & $\square$ & $\square$ \\
\hline 8 & RE4 & $\begin{array}{l}\text { 4. Special and complex transactions are concerned and strongly } \\
\text { supported. }\end{array}$ & $\square$ & $\square$ & $\square$ & $\square$ & $\square$ \\
\hline \multicolumn{8}{|c|}{ Responsiveness* } \\
\hline 9 & RS1 & $\begin{array}{l}\text { 1. The bank provides various types of products and services to } \\
\text { meet customers' demands. }\end{array}$ & $\square$ & $\square$ & $\square$ & $\square$ & $\square$ \\
\hline 10 & RS2 & 2. The bank has reasonable, flexible and competitive service fees. & $\square$ & $\square$ & $\square$ & $\square$ & $\square$ \\
\hline 11 & RS3 & 3. The processing time are quick and prompt way. & $\square$ & $\square$ & $\square$ & $\square$ & $\square$ \\
\hline 12 & RS4 & 4. Customers' feedbacks and complaints are well-handled. & $\square$ & $\square$ & $\square$ & $\square$ & $\square$ \\
\hline \multicolumn{8}{|c|}{ Assurance* $^{*}$} \\
\hline 13 & AS1 & $\begin{array}{l}\text { 1. Banking staffs have high level of competence in procedures, } \\
\text { regulations and international customs. }\end{array}$ & $\square$ & $\square$ & $\square$ & $\square$ & $\square$ \\
\hline 14 & AS2 & $\begin{array}{l}\text { 2. Staffs are always willing to support customers and have good } \\
\text { serving attitude. }\end{array}$ & $\square$ & $\square$ & $\square$ & $\square$ & $\square$ \\
\hline 15 & AS3 & $\begin{array}{l}\text { 3. The bank is highly credible and on the top choice for } \\
\text { International Payment service. }\end{array}$ & $\square$ & $\square$ & $\square$ & $\square$ & $\square$ \\
\hline \multicolumn{8}{|c|}{ Convenience* $^{*}$} \\
\hline 16 & CO1 & 1. The bank has wide correspondent network. & $\square$ & $\square$ & $\square$ & $\square$ & $\square$ \\
\hline 17 & $\mathrm{CO} 2$ & $\begin{array}{l}\text { 2. The bank has many transaction locations which is convenient for } \\
\text { customers. }\end{array}$ & $\square$ & $\square$ & $\square$ & $\square$ & $\square$ \\
\hline 18 & $\mathrm{CO} 3$ & 3. Transaction procedures are easy, simple and proper. & $\square$ & $\square$ & $\square$ & $\square$ & $\square$ \\
\hline
\end{tabular}

\section{Evaluation of service quality - Part II}

For each question below, your level of approval for BIDV's international payment activities is calculated by increasing the scale from 1 to 5:

1 - Very disagreed

2- Not agreed

3- Normal

4- Agreed

5- Strongly agreed 
(*): Required questions

\begin{tabular}{|l|l|l|l|l|l|l|l|}
\hline \multicolumn{2}{|l|}{ Service quality* } \\
\hline 19 & SER1 & The overall of IP serivce quality at BIDV meet my needs & $\square$ & $\square$ & $\square$ & $\square$ & $\square$ \\
\hline 20 & SER2 & I am satisfied with IP service quality at BIDV & $\square$ & $\square$ & $\square$ & $\square$ & $\square$ \\
\hline 21 & SER3 & I will introduce IP service at BIDV to others & $\square$ & $\square$ & $\square$ & $\square$ & $\square$ \\
\hline
\end{tabular}

23. If you have any suggestions about service quality of BIDV's international payment activities, please write down in below blank:

End of the survey (for those who have used International Payment service at BIDV)

Thank you! 